\title{
First confirmed records of the rare Short-eared Bat, Cyttarops alecto Thomas, 1913 (Chiroptera: Emballonuridae), from the Orinoco Llanos of Colombia
}

\author{
María C. Calderón-Capote ${ }^{1,2}$, Darwin M. Morales-Martínez ${ }^{1,2}$, Camilo Fernández-Rodríguez ${ }^{1}$ and \\ Miguel E. Rodríguez-Posada ${ }^{1,2 *}$
}

1 Fundación Reserva Natural La Palmita, Centro de Investigación, Grupo de investigaciones territoriales para el uso y conservación de la biodiversidad, carrera 4 No 58 - 59, Bogotá, Colombia

2 Universidad Nacional de Colombia, sede Bogotá, Instituto de Ciencias Naturales, Grupo de Mastozoología, Grupo en Conservación y Manejo de Vida Silvestre, carrera 30 \# 45-03 edifico 425, Bogotá, Colombia

* Corresponding author. E-mail: director.cientifico@lapalmita.com.co

\begin{abstract}
We confirm the occurrence of the rare bat Cyttarops alecto in piedmont and alluvial plain savannas of the Orinoco Llanos. Our records are the first for the species in Colombia in 22 years. The species was known only from Neotropical rainforests and one locality in the Cerrado formation in Brazil. Our records are supported with voucher specimens that match the diagnosis and variability described for the species. With these records, we reduce the geographical distribution gap between known Trans-Andean and Cis-Andean localities of this species in the northern Neotropics.
\end{abstract}

Key words: Diclidurini; Casanare; Neotropical flooded savannas; gallery forest; geographic distribution; range extension

The Short-eared Bat, Cyttarops alecto Thomas, 1913, is considered one of the rarest Neotropical bats, known only by 27 specimens from 19 localities (Lim et al. 2008; Rivas Rodríguez and Ferrer Pérez 2012; Tavares et al. 2012). Despite the scarcity of documented records, this species is widely distributed in lowland forests below $500 \mathrm{~m}$ above sea level (a.s.l.) from Nicaragua to Brazil and Bolivia (Ochoa et al. 1994; Hood and Gardner 2008; Lim et al. 2008; Aguirre et al. 2010). Currently, the known geographic distribution of $C$. alecto has a wide gap between Central and South America: the nearest localities in Central America are in Barro Colorado, Panama, while the records in South America belong to the Guiana region near the Caura River (Venezuela) and Amazonian region in Leticia (Colombia). The distance between these localities is between $1,600 \mathrm{~km}$ to 1,800 $\mathrm{km}$. This may suggests that the distribution of this species in northern South America is poorly known.
In Colombia, C. alecto was known from only one specimen that was captured in 1972 in Leticia, department of Amazonas (Ochoa et al. 1994; Solari et al. 2013). Later, Cuervo et al. (1986) reported the species from the lowlands of Colombia, and Alberico et al. (2000) reported it from the department of Vichada. The latter record is based on material deposited at Instituto de Investigación de Recursos Biológicos Alexander von Humboldt, Villa de Leyva (IAvH). However, neither Cuervo et al. (1986) nor Alberico et al. (2000) provided catalogue numbers of vouchers or specific localities to confirm this species' distribution. The hypothesis is that the distribution of C. alecto in Colombia comprises the Amazonian region south of the Putumayo River, and that the presence of the species in the Caribbean and Orinoco regions is still uncertain (Mantilla-Meluk et al. 2014).

Herein, we present the first confirmed records of C. alecto from the Orinoco Llanos of Colombia. Our records come from two different natural regions following Sarmiento (1983): the piedmont savannas and the alluvial plains. We also looked for specimens in the mammal collection of $\mathrm{IAvH}$ that would support the previous report of this species by Alberico et al. (2000). We comment the morphological variation of the species based on our material and that previously described in the literature. Additionally, we provide insights on the habitats of the species.

We consulted specimens housed in the mammalian collection "Alberto Cadena García" of Instituto de Ciencias Naturales of the Universidad Nacional de Colombia (ICN), and the collection of mammals of IAvH. External measurements were transcribed from specimen tags. Forearm and skull measurements were taken following Simmons and Voss (1998) with digital calipers to the nearest $0.01 \mathrm{~mm}$. 


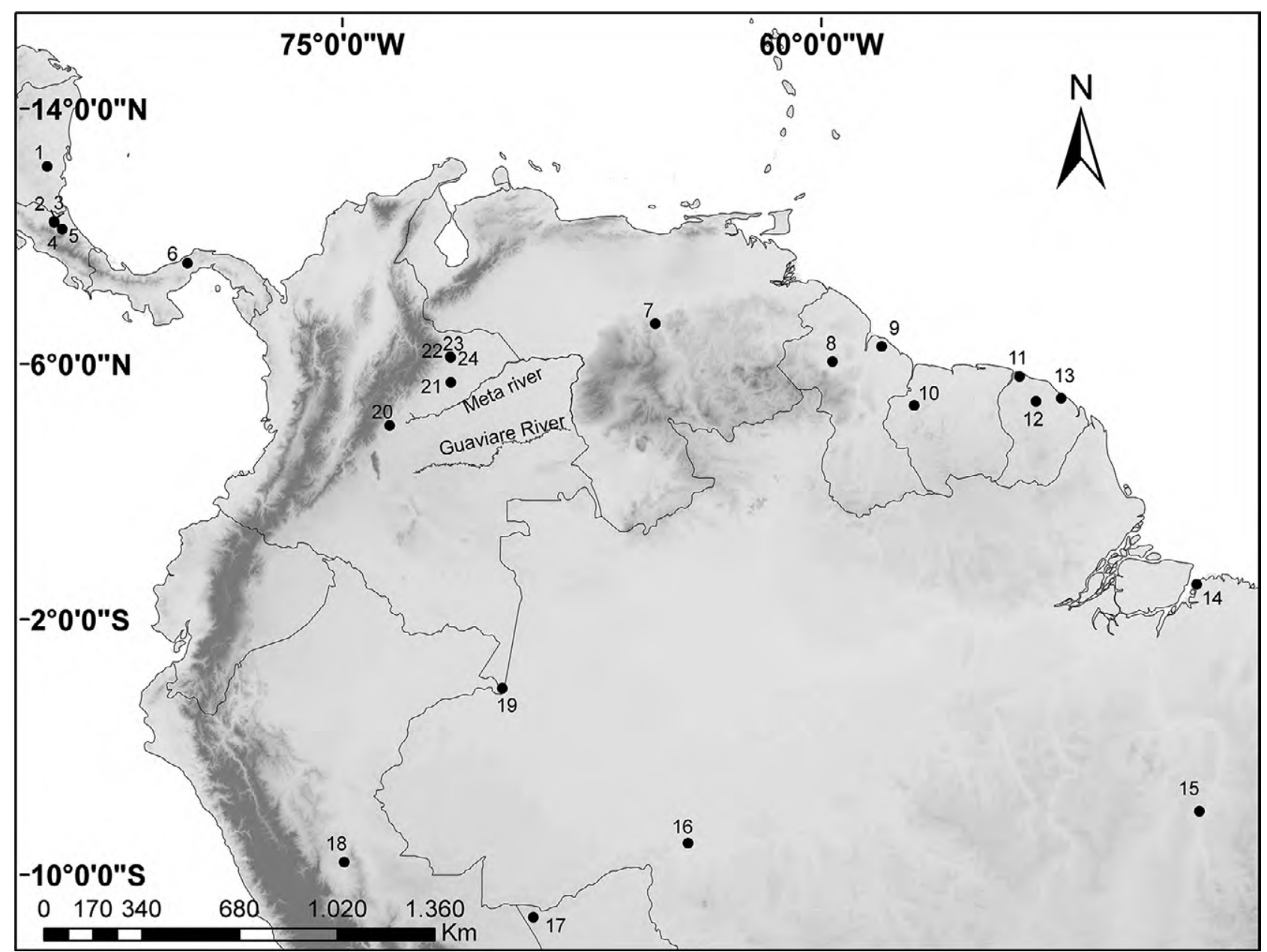

Figure 1. Localities of Cyttarops alecto, from Central and South America. Nicaragua: 1. 4.5 km northwest of Rama, Región Autónoma del Atlántico Sur (Baker and Jones 1975); Costa Rica: 2. Puerto Viejo de Sarapiquí (Starrett 1972); 3. La Selva Biological Station (Jung et al. 2007); 4. Tortuguero Lodge, Tortuguero (Limon; Reid and Langtimm 1993); 5. Estación Experimental Los Diamantes, (Starrett 1972); Panama: 6. Barro Colorado Island (Jung et al. 2007); Venezuela: 7. Suapure Sector, Caura River, Bolivar state (Rivas and Ferrer 2010); Guyana: 8. Mazaruni River, approximate location (Thomas 1913); 8. CEIBA Biological Center (Lim 2007); Suriname: 10. Blanche Marie Vallen ecotourism facility, Guesthouse Dubois (Lim 2009); French Guiana: 11. 3.5 km WSW of Acarouany, south of the municipal road D10 (Velazco et al. 2011); 12. Station de la Piste de St. Elie (ECEREX) (Masson and Cosson 1992); 13. 2.8 km south of Tonate (Macouria) (Velazco et al. 2011); Brazil: 14. Mocajatuba, Pará state (Thomas 1913); 15. Palmeirante, Tocantins state (Nunes et al. 2006); 16. Morrinhos, Rondônia state (Tavares et al. 2012); Bolivia: 17. Estación Biológica Tahuamanu (Aguirre et al. 2010); Peru: 18. Panguana Biological Station (Velazco et al. 2011); Colombia: 19. 35-40 Km in the road to Calderón, Leticia, Amazonas department (Ochoa et al. 1994); 20. ICN 21656 Hacienda El Hachón, Villavicencio, Meta department (this study). 21. ICN 21910 Reserva Natural La Palmita Centro de Investigación in Trinidad, Casanare department (this study); 22. ICN 21911 Río Casanare, finca La Providencia, vereda La Manga in Hato Corozal, Casanare department (this study); 23. ICN 21912 Caño Yaguarapo, finca La Reserva, vereda la Manga in Hato Corozal, Casanare department (this study); 24. IAvH (Temp-ABJ690; RCFR 392) Caño Yaguarapo, finca La Reserva, vereda La Manga in Hato Corozal, Casanare department (this study).

Our record from piedmont savannas corresponds to an adult female (ICN 21656) found in the uncatalogued specimens of the collection of mammals of ICN. The specimen was collected by Alberto Cadena in 1982 in Hacienda el Hachón near Villavicencio city (Figure 1. Table 1). The locality is characterized by alluvial fans, and terraces dominated by savannas with semideciduous forest corridors along the rivers and creeks. We collected additional records (ICN 21910, 21911, 21912) and IAvH (Temp-ABJ690; RCFR 392) in alluvial plains in 2015 using ground mist nets in territories of the department of Casanare (Figure 1; Table 1). Captures were made under the research permit 500-4115.07209 of CORPORINOQUIA and by the agreement
15-14-172-010CE with the Instituto de Investigación de Recursos Biológicos Alexander von Humboldt. These records were found in alluvial flood plains that occupy a vast depression in the central llanos where the hyperseasonal savanna ecosystem is most widespread. This savanna is mainly treeless and dominated by grasses and riparian forest patches that are flooded during the rainy period (Sarmiento 1983).

We found only one specimen identified as $C$. alecto (IAvH 1323, from Vichada department, Colombia) in the collection of mammals of the IAvH; however, this specimen corresponds to Myotis nigricans Schinz, 1821. Therefore, we consider uncertain the distribution of $C$. alecto in Vichada department. 
Table 1. Specimens reported here. Museum number, Locality, geographic coordinates, altitude and Natural regions: Piedmont savannas ${ }^{1}$. Alluvial plain savannas ${ }^{2}$.

\begin{tabular}{|c|c|c|c|}
\hline Museum numbers & Localities & Geographic coordinates & Altitude \\
\hline ICN $21656^{1}$ & Hacienda El Hachón, municipality of Villavicencio, department of Meta & $05^{\circ} 03^{\prime} 47^{\prime \prime} \mathrm{N}, 073^{\circ} 30^{\prime} 56^{\prime \prime} \mathrm{W}$ & $300 \mathrm{~m}$ \\
\hline ICN $21910^{2}$ & $\begin{array}{l}\text { Reserva Natural La Palmita, Centro de Investigación, vereda La Cañada, municipality of } \\
\text { Trinidad, department of Casanare }\end{array}$ & $05^{\circ} 24^{\prime} 52^{\prime \prime} \mathrm{N}, 071^{\circ} 35^{\prime} 43^{\prime \prime} \mathrm{W}$ & $160 \mathrm{~m}$ \\
\hline ICN $21911^{2}$ & $\begin{array}{l}\text { Casanare River, La Providencia farm, vereda La Manga, municipality of Hato Corozal, } \\
\text { department of Casanare }\end{array}$ & $06^{\circ} 13^{\prime} 40^{\prime \prime} \mathrm{N}, 071^{\circ} 37^{\prime} 00^{\prime \prime} \mathrm{W}$ & $174 \mathrm{~m}$ \\
\hline $\begin{array}{l}\text { ICN 21912, IAvH (Temp-ABJ690; } \\
\text { RCFR 392) }\end{array}$ & $\begin{array}{l}\text { Caño Yaguarapo, La Reserva farm, vereda La Manga, municipality of Hato Corozal, } \\
\text { department of Casanare }\end{array}$ & $06^{\circ} 11^{\prime} 54^{\prime \prime} \mathrm{N}, 071^{\circ} 36^{\prime} 14^{\prime \prime} \mathrm{W}$ & $168 \mathrm{~m}$ \\
\hline
\end{tabular}

Cyttarops alecto is an aerial insectivore emballonourid, characterized by its moderate size (forearm 40-47 $\mathrm{mm}$ ), smoky gray pelage, and the lack of wing sacs or glands in the uropatagium. The skull exhibits a deep cuplike depression in the rostrum and the postorbital processes are long and not fused to the supraorbital ridge (Hood and Gardner 2008). All specimens have the external and cranial diagnosed characters mentioned above (Figures 2 and 3; Jones and Hood 1993; Hood and Gardner 2008). However, our specimens show variation in some recently reported characters, such as a diastema between the upper premolars, a naked patch of skin over the front head, and a posterior ventral process of the mandible (Velazco et al. 2011; Tavares et al. 2012). In our material, the diastema between the upper premolars remains, but do not have a naked patch of skin over the front head. The posterior ventral process of the mandible presents intraspecific variation from completely absent to highly developed, including specimens from the same locality and the same sex
(ICN 21912 and IAvH-Temp-ABJ690 [RCFR 392]).

Measurements of our records concur with earlier reports from Brazil (Thomas 1913; Nunes et al. 2006; Tavares et al. 2012), Peru (Velazco et al. 2011), French Guiana (Masson and Cosson 1992), Nicaragua (Baker and Jones 1975), Costa Rica (Starrett and de la Torre 1964; Starrett and Casebeer 1968; Reid and Langtimm 1993), and Colombia (Ochoa et al. 1994) and show no evidence of notable variation throughout the species range (Table 2). Therefore, the external and craneo-dental measurements suggest that despite the lack of material available the morphological dissimilarities (see above) do not necessary represent geographic variations or different taxonomic entities as suggested by Velazco et al. (2011).

Our records are the first known from savanna ecosystems in northern South America. All previous localities for the species were in Amazonian and Guiana rainforests, Trans-Andean rainforests of Central America, and the Brazilian Cerrado (Thomas 1913; Starrett and de la Torre 1964; Starrett and Casebeer 1968;

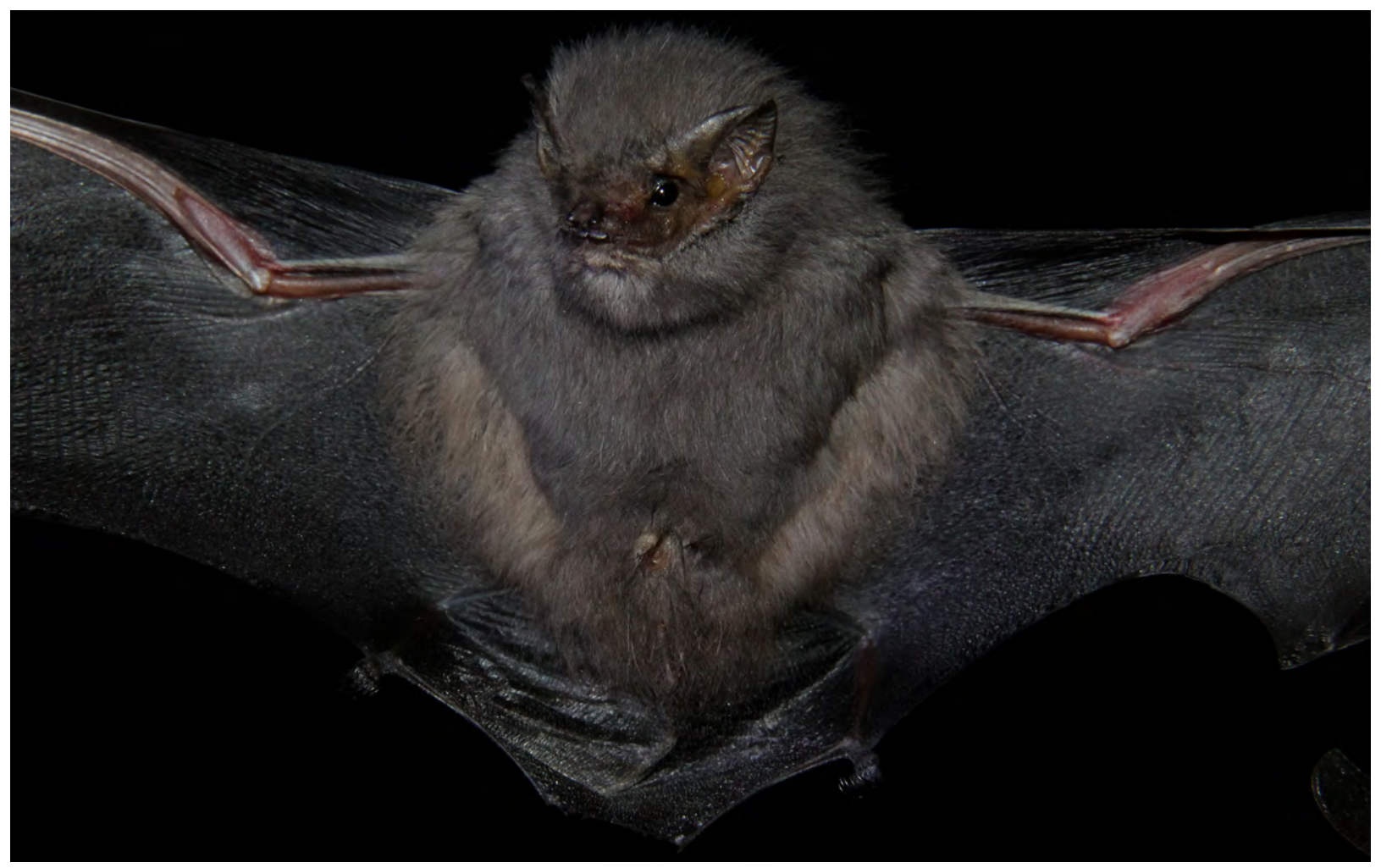

Figure 2. Individual of Cyttarops alecto collected at Casanare River, Finca La Providencia, vereda La Manga in Hato Corozal, Casanare Department (ICN 21911). Photograph: María C. Calderón-Capote. 


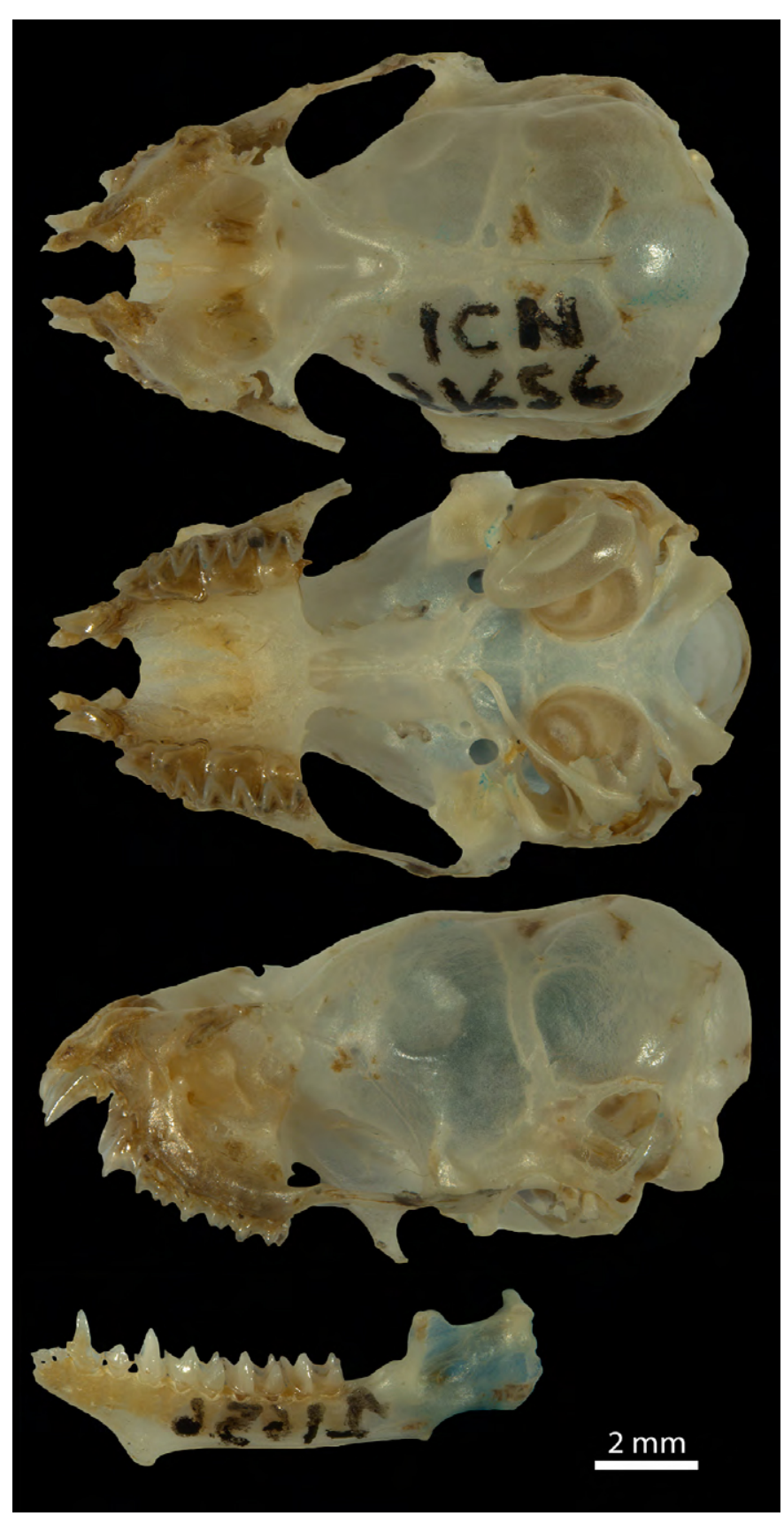

Baker and Jones 1975; Masson and Cosson 1992; Reid and Langtimm 1993; Ochoa et al. 1994; Nunes et al. 2006; Velazco et al. 2011; Rivas Rodríguez and Ferrer Pérez 2012; Tavares et al. 2012). Although the floristic composition is different between Brazilian Cerrado and Orinoco Llanos of Colombia, landscape similarities are evident showing savanna influence (Sarmiento 1983). The occurrence of the species in other natural regions of South America, such as the Orinoco Llanos, means that these can provide additional roosts and suitable habitats for the species to inhabit, suggesting the ability of $C$. alecto to adapt to different environments (Starrett 1972; Velazco et al. 2011; Tavares et al. 2012).

The current distribution of this species in the Orinoco Llanos suggests that it may occur elsewhere in the region including the portion of the Llanos and Amazon in Venezuela. The new records documented here for the northern Neotropics reduce the distribution gap between the Cis-Andean and Trans-Andean regions and suggests the presence of the species in other lowlands of Colombia.

Although it has been suggested that ground mist nets are not appropriate to survey this type of bats (Velazco et al. 2011), all the specimens from Casanare were captured using this technique at ground level in clearings and along roads inside forests that are characterized by an abundance of palms as reported by Ochoa et al. (1994). However, the scarcity of material of C. alecto implies that bat sampling methods must include different approaches, such as canopy and subcanopy mist nests in addition to echolocation call recordings, as a way of maximizing the data collection.

Figure 3. Dorsal (upper), ventral (middle) and lateral (lower) views of the skull and lateral view of the mandible of Cyttarops alecto (ICN 21656). Middle arrows: diastema between the upper premolars; bottom arrow: posterior ventral process of the mandible.

Table 2. Range of external and skull measurements $(\mathrm{mm})$ and body mass $(\mathrm{g})$ of Cyttarops alecto based on all previous records summarize by Tavares et al. (2012) and mean and range of male specimens report here. Abbreviations: Total body length (TL), Tail length (TV), Hind foot length (HF), Ear length (EAR), Forearm length (FA), Greatest length of the skull (GLS), Condylobasal length (CBL), Zygomatic breadth (ZB), Mastoid breadth (BM), Braincase breadth (BBC), Maxillary toothrow length (CM3), Breadth across molars (M3M3). Specimen: fluid preserved with skull removed', Skin, skull and body specimen².

\begin{tabular}{|c|c|c|c|}
\hline Measurements & Tavares et al. (2012: table 1) & ICN $21656^{1}$ & ICN 21910', $21911^{2}, 21912^{1}$, IAvH$^{\prime}$ (Temp-ABJ690 [RCFR 392]) \\
\hline Sex & 9 Female; 4 Male & Female & 4 Males \\
\hline Weight (g) & $6-8$ & - & $5.5(5-6)$ \\
\hline TL & $50.0-75.0$ & - & $70.5(63-78)$ \\
\hline TV & $18.0-25.0$ & - & $22.0(15-26)$ \\
\hline $\mathrm{HF}$ & $5-10$ & - & $8(7-9)$ \\
\hline EAR & $10-12$ & - & $14(13-15)$ \\
\hline FA & $45.3-47.2$ & 45.9 & $42.87(41.60-44.15)$ \\
\hline GLS & $12.6-14.3$ & 13.9 & $13.22(13.12-13.33)$ \\
\hline CBL & $12.3-13.2$ & 13.2 & $12.02(11.80-12.33)$ \\
\hline ZB & $8.0-8.7$ & - & $8.27(8.15-8.44)$ \\
\hline BM & $7.4-7.7$ & 7.5 & $7.23(7.10-7.45)$ \\
\hline $\mathrm{BBC}$ & $6.8-7.1$ & 6.7 & $6.62(6.46-6.89)$ \\
\hline $\mathrm{CM} 3$ & $5.1-5.6$ & 5.4 & $5.24(5.13-5.36)$ \\
\hline M3M3 & $5.9-6.3$ & 5.9 & $5.77(5.69-5.93)$ \\
\hline
\end{tabular}




\section{ACKNOWLEDGEMENTS}

We give special thanks to Hugo López Arevalo (ICN), Catalina Cárdenas González (ICN), and Claudia Medina $(\mathrm{IAvH})$ for permitting us to study specimens under their care. We also sincerely thank our field assistants and the farm proprietors. Laboratorio de Equipos Ópticos Compartidos (LEOC) from the Departamento de Biología of Facultad de Ciencias, Universidad Nacional de Colombia provided photographic assistance of Figure 3. The specimens collected from the municipality of Hato Corozal, Casanare, were obtained during the project: "Conservación de especies amenazadas en el área de influencia del Oleducto Bicentenario, Convenio de cooperación No. 15-14-172-010CE between the Instituto de Investigación de Recursos Biológicos Alexander von Humboldt and the Fundación Reserva Natural La Palmita, Centro de Investigación". The specimens collected from municipality of Trinidad, Casanare, were obtained during the project "Programa de diagnóstico y monitoreo de la diversidad biológica de las sabanas inundables para la evaluación de su integridad ecológica. Primera etapa: Mamíferos y aves, orden de servicio OS 411000797 between Parex Resources Ltda., and the Fundación Reserva Natural La Palmita, Centro de Investigación." Héctor Ramírez Chaves and Camilo A. Calderón-Acevedo reviewed an early version of the manuscript. Two anonymous reviewers provided comments to the final version.

\section{LITERATURE CITED}

Aguirre, L.F., C.J. Mamani, K. Barbosa-Marquez and H. MantillaMeluk. 2010. Lista actualizada de los murciélagos de Bolivia. Revista Boliviana de Ecología y Conservación Ambiental 27: 1-7.

Alberico M.; Cadena A.; Hernández-Camacho J.I. and Y. Muñoz-Saba. 2000. Mamíferos (Synapsida: Theria) de Colombia. Biota Colombiana 1: 43-75. http://www.redalyc.org/pdf/491/49110103.pdf

Baker, R.J. and J.K.Jr. Jones 1975. Additional records of bats from Nicaragua, with a revised checklist of Chiroptera. Occasional Papers, the Museum Texas Tech University 32: 1-13. http:// www.nsrl.ttu.edu/publications/opapers/ops/OP32.pdf

Cuervo-Díaz, A., J.I. Hernández-Camacho and A. Cadena. 1986. Lista actualizada de los mamíferos de Colombia anotaciones sobre su distribución. Caldasia 15: 71-75. http://www.revistas.unal.edu. co/index.php/cal/article/view/35095/35366

Hood, C. and A.L. Gardner. 2008. Family Emballonuridae; pp. 188-189, in: A.L. Gardner (ed.). Mammals of South America. Volume 1. Marsupials, xenarthrans, shrews, and bats. Chicago: The University of Chicago Press.

Jones, J.K. Jr. and C.S. Hood. 1993. Synopsis of South American bats of the family Emballonuridae. Occasional Papers the Museum Texas Tech University 155: 1-32. http://www.nsrl.ttu.edu/ publications/opapers/ops/OP155.pdf

Jung, K., E.K.V. Kalko and O. von Helversen. 2007. Echolocation calls in Central American emballonurid bats: signal design and call frequency alternation. Journal of Zoology 212(2): 125-137. doi: 10.1111/j.1469-7998.2006.00250.x

Lim, B.K. 2007. Divergence times and origin of Neotropical sheath-tailed bats (tribe Diclidurini) in South America. Molecular Phylogenetics and Evolution 45: 777-791. doi: 10.1016/j.ympev. 2007.09.003

Lim, B., B. Miller, F. Reid, J. Arroyo-Cabrales, A.D. Cuarón and P.C. de Grammont. 2008. Cyttarops alecto. The IUCN Red List of threatened species. e.T6206A12579382. Accessed at http:// www.iucnredlist.org, 13 May 2016. doi: 10.2305/IUCN.UK.2008.
RLTS.T6206A12579382.en

Lim, B.K. 2009. Environmental assessment at the Bakhuis Bauxite Concession: small-sized mammal diversity and abundance in the lowland humid forests of Suriname. The Open Biology Journal 2: 42-53. doi: 10.2174/1874196700902010042

Mantilla-Meluk, H., H.E. Ramírez-Chaves, A.M. Jiménez-Ortega and M.E. Rodríguez-Posada. 2014. Emballonurid bats from Colombia: annotated checklist, distribution, and biogeography. Therya 29: 229-255. doi: 10.12933/therya-14-189

Masson, D. and J.F. Cosson. 1992. Cyttarops alecto (Emballonuridae) et Lasiurus castaneus (Vespertilionidae), deux chiroptères nouveaux pour la Guyane française. Mammalia 56: 475-478.

Nunes, A., S.A. Marques-Aguiar, N. Saldanha and R.S. Silva. 2006. On the distribution and rarity of the Neotropical bat Cyttarops alecto (Chiroptera: Emballonuridae). Mammalia 70: 173. doi: 10.1515/MAMM.2006.032

Ochoa, G.J., P.J. Soriano and J. Hernandez-Camacho. 1994. Sobre la presencia de Cyttarops alecto (Chiroptera: Emballonuridae) en Colombia. Trianea 5: 411-414

Reid, F.A. and C.A. Langtimm. 1993. Distributional and natural history notes for selected mammals from Costa Rica. The Southwestern Naturalist 38: 299-302. doi: 10.2307/3671441

Rivas Rodríguez, B and A. Ferrer Pérez. 2012. Primer registro de Cyttarops alecto Thomas 1913 (Chiroptera: Emballonuridae) para Venezuela. Memoria de la Fundación La Salle de Ciencias Naturales 173-174: 275-278.

Sarmiento, G. 1983. The savannas of tropical America; pp. 245-288, in: F. Bourliere (ed.) Ecosystems of the world XIII. Tropical savannas. Amsterdam: Elsevier.

Simmons, N.B. and R.S. Voss. 1998. The mammals of Paracou, French Guiana: a Neotropical lowland rainforest fauna, Part 1. Bats. Bulletin American Museum of Natural History 237: 1-219. http://digitallibrary.amnh.org/handle/2246/386

Solari, S., Y. Muñoz-Saba, J. V. Rodríguez-Mahecha, T. R. Defler, H. E. Ramírez-Chaves and F. Trujillo. 2013. Riqueza, endemismo y conservación de los mamíferos de Colombia. Mastozoología Neotropical 20(2): 301-365. doi: http://www.scielo.org.ar/pdf/ mznt/v20n2/v20n2a08.pdf

Starrett, A. and L. de la Torre. 1964. Notes on a collection of bats from Central America, with the third record for Cyttarops alecto Thomas. Zoologica 49: 53-63.

Starrett, A. and R.S. Casebeer. 1968. Records of bats from Costa Rica. Contributions in Science Los Angeles County Museum 148: 1-21. http://www.nhm.org/site/sites/default/files/pdf/contrib_ science/CS148.pdf

Starrett, A. 1972. Cyttarops alecto. Mammalian Species 13: 1-2.

Tavares, V., P.E.D. Bobrowiec and S.G. Farias. 2012. First record of the rare bat Cyttarops alecto (Thomas, 1913) (Chiroptera: Emballonuridae) for the western Brazilian Amazonia, with comments on the type locality. Mammalia 76: 345-349. doi: 10.1515/ mammalia-2011-0117

Thomas, O. 1913. On some rare Amazonian mammals from the collection of the Pará Museum. Annals and Magazine of Natural History 11: 130-136. doi: 10.1080/00222931308693297

Velazco, S., V. Pacheco and A. Meschede. 2011. First occurrence of the rare emballonurid bat Cyttarops alecto (Thomas, 1913) in Peruonly hard to find or truly rare? Mammalian Biology 76: 373-376. doi: 10.1016/j.mambio.2010.03.006

Authors contributions: All authors wrote the paper. MCC, DMM, RCFR collected, recorded all morphological data and identified the specimens. DMM made the map, MCC took the cranial photographs and MRP coordinated the researchers work.

Received: 21 May 2016

Accepted: 11 September 2016

Academic editor: Sergio Solari 